\title{
Påvirket vaksine og hygieneråd pandemien?
}

I juni 2009 erklærte WHO århundrets første influensapandemi. Den norske pandemiplanen skulle settes ut i livet. Denne omhandlet en rekke forebyggende tiltak, både farmakologiske og fysiske (1). Vaksine var krumtappen i beredskapen, og store ressurser gikk med til å sikre god forsyning og rask distribusjon. I tillegg ga helsemyndighetene råd om hvordan befolkningen kunne beskytte seg på annet vis, bl.a. med god hoste- $\mathrm{g}$ håndhygiene. Men er det sannsynlig at disse tiltak påvirket pandemiens utvikling i Norge? To epidemiologiske studier i dette nummer av Tidsskriftet berører denne problemstillingen.

Den første studien tar utgangspunkt i legevaktkonsultasjoner og sammenlikner nasjonal forekomst av visse infeksjonsdiagnoser siste halvår 2009 med de samme måneder de tre foregående år (2). Studiens design gjør at effekt av hygiene på influensa ikke kan vurderes, men undersøkelsen viser en nedgang i flere andre infeksjonssykdommer som forfatterne mener kan ha sammenheng med myndighetenes hygieneråd. Resultatene støtter funn fra en metaanalyse der det samlet sett ble konkludert med at forbedring $\mathrm{i}$ håndhygiene reduserer gastrointestinale infeksjoner med $31 \%$ og luftveisinfeksjoner med $21 \%$ (3). Fordi luftveisinfeksjoner også kan spres med hoste, er det trolig at man ved hostehygiene kan oppnå mer enn med håndhygiene alene. Vi mangler imidlertid fortsatt god dokumentasjon på hvilken forebyggende effekt befolkningsrettede hygieneråd har på influensa.

Artikkelen om pandemihåndtering i Austevoll kommune viser at belastningen på helsetjenesten var meget stor (4). Resultatene tyder på at vaksinasjonskampanjen hadde liten effekt på utviklingen av den lokale epidemien, som allerede hadde kulminert da vaksinasjon for alvor kom i gang. Data fra denne og andre studier sannsynliggjør allikevel at vaksinen var effektiv for dem som fikk den i tide. I England og Skottland fant man $71 \%$ beskyttende effekt av pandemivaksine etter en uke (5).

Epidemiologiske studier har en rekke utfordringer. Det bør foreligge en presis sykdomsdefinisjon som sikrer at samme tilstand får samme diagnose av forskjellige leger over tid. Dette savnes for de diagnosene som inngår i de ovennevnte norske undersøkelsene, hvor diagnosene i hovedsak ble stilt på basis av klinisk skjønn $(2,4)$. Det er ikke usannsynlig at det store fokus på influensa siste halvår 2009 førte til en økning av influensadiagnoser på bekostning av andre infeksjoner med overlappende symptomatologi. Dette kan ha ført til observasjonsskjevhet. Videre er det mulig at befolkningens terskel for å søke lege endret seg under pandemien, bl.a som følge av forlenget egenmeldingsperiode og at valg av legetjenester skilte seg fra tidligere år. Slike forhold kan ha forårsaket seleksjonsskjevhet.

Selv om det skulle være en reell nedgang av visse infeksjoner i Norge under pandemien, kan man ikke konkludere med at dette var et resultat av hygienekampanjen. Kanskje var nedgangen et resultat av andre forhold, f.eks at alle med influensaliknende symptomer lenge ble oppfordret til å holde seg hjemme én uke etter sykdomsdebut. Kanskje ville hygienen ha blitt bedre uavhengig av rådene. Og kanskje finnes andre biologiske forklaringer på forskjellene i onsultasjonsrater i studieperioden. Forekomst av mange smittsomme sykdommer har naturlige svingninger i løpet av årstidene og fra år til år, noe som gjør det generelt vanskelig å beregne effekten av en intervensjon ved å sammenlikne insidensrater i perioden før og etter denne.
Det vil derfor ved epidemiologiske studier av en pandemi være betydelig usikkerhet knyttet til vurdering av intervensjoner som vaksine og hygieneråd. En randomisert kontrollert undersøkelse regnes gjerne som gullstandarden for studiedesign, men ville vanskelig la seg gjennomføre for å vurdere nasjonale effekter av hygienetiltak. Av etiske grunner ville en randomisert undersøkelse av vaksine heller ikke la seg gjennomføre under en pandemi. Derfor har epidemiologiske studier allikevel en plass i evalueringen av igangsatte intervensjoner. Direktoratet for samfunnssikkerhet og beredskap konkluderte i sin evaluering av pandemiberedskapen med at «hygienerådene må sies å være en suksess», uten at man kunne måle effekten (6). Rapporten anslår at 1,2 millioner mennesker utenfor risikogruppene ble vaksinert og at man med dette kan ha spart 2-6 liv. Vi vet nå at den siste pandemien var mildere enn fryktet. Allikevel var helsetjenesten hardt presset $\mathrm{i}$ noen hektiske måneder. I ettertid vil mange hevde at de ressurser som ble mobilisert, ikke sto i rimelig forhold til eventuelle gevinster. Det var imidlertid ikke gitt noen å forutse dette da man i 2009 måtte ta avgjørelsen om aktivering av pandemiplaner. Beredskapstiltak må alltid ta høyde for at utviklingen kan bli verre enn det som synes mest sannsynlig i en tidlig fase, og åpenhet er avgjørende for befolkningens tillit. Kinesiske myndigheters håndtering av sarsepidemiens første måneder er et eksempel på hvor galt det kan gå i motsatt fall.

I Norge har man i løpet av noen hundre år sett en dramatisk reduksjon i forekomst av alvorlige infeksjoner. Både bedring i hygieniske kår og vaksinasjon har bidratt til dette. Ignaz Semmelweis møtte stor motstand da han viste at barselfeber kunne forebygges med god håndhygiene. Fortsatt kan smittevern vekke heftig debatt i fagmiljøene, for eksempel bruk av munnbind utenfor helsetjenesten, munnbind kontra åndedrettsvern på sykehus og råd om å hoste i albukroken. I en tid da vi trues av antibiotikaresistens og nye infeksjoner, trengs fortsatt forskning på effekten av vaksine og hygienetiltak.

\section{Arne Broch Brantsæter}

uxarbr@ous-hf.no

Arne Broch Brantsæter (f. 1959) er overlege ved infeksjonsmedisinsk avdeling og NBC-senteret ved Oslo universitetssykehus, Ullevål. Han har tidligere arbeidet ved Folkehelseinstituttet, bl.a. med beredskap mot sars og influensa.

\section{Oppgitte interessekonflikter: Ingen}

\section{Litteratur}

1. Nasjonal beredskapsplan for pandemisk influensa. Oslo: Helse- og omsorgsdepartementet, 2006

2. Sandvik H, Hunskår S. Hygienekampanjen høsten 2009 - færre infeksjonstilfeller på legevakt? Tidsskr Nor Legeforen 2011; 131: 680-2.

3. Aiello AE, Coulborn RM, Perez V et al. Effect of hand hygiene on infectious disease risk in the community setting: a meta-analysis. Am J Public Health 2008; 98: 1372-81

4. Rørtveit S, Hunskår S, Wensaas K-A et al. Influensapandemien hausten 2009 ein vestlandskommune. Tidsskr Nor Legeforen 2011; 131: 675-9.

5. Hardelid P. Fleming DM, McMenamin J et al. Effectiveness of pandemic and seasonal influenza vaccine in preventing pandemic influenza A(H1N1)2009 infection in England and Scotland 2009-2010. Euro Surveill 2011; 16: pii 19763.

6. Ny influensa A(H1N1) 2009. Gjennomgang av erfaringene i Norge. Tønsberg: Direktoratet for samfunnssikkerhet og beredskap, 2010. 